\title{
(죠
}

\section{Case Presentation of Acute Pancreatitis Related to Steroid Therapy}

\author{
Steroid Kullanımına Bağlı Gelişen Akut Pankreatit: Bir Olgu Sunumu
}

Mehmet Gül, Esma Erdemir, Başar Cander, Sadık Girişgin, Mehmet Ergin, Sedat Koçak

Selçuk Üniversitesi Meram Tıp Fakültesi, Acil Tıp Anabilim Dalı, Konya, Türkiye

\begin{abstract}
Acute pancreatitis (AP) is an acute clinical state which generally results from inflammation of the pancreas and typically presents with abdominal pain and high levels of pancreatic enzymes in the blood and urine. A twenty-five year -old woman admitted to emergency service with complaints of abdominal pain spreading back and unremitting, nausea and vomitting during the previous four days. Her medical history was unremarkable. It was learned that her abdominal pain began after she was treated with methylprednisolone 120 mg intravenously 15 days earlier. Her physical examination showed sensitivity and rebound in theepigastric region. Levels of amylase and lipase were $957 \mathrm{U} / \mathrm{L}$ (normal range 36-128) and $1193 \mathrm{U} / \mathrm{L}$ (normal range: 22-51), respectively. Abdominal computer tomography of the pancreas reported that the head region was wider than normal and heterogenous. The second part of the duodenum had diffuse wall thickening. Since no reason other than drug was found, steroid therapy was discontinued. Oral intake was stopped and fluid and electrolyte replacement were begun parenterally. The levels of amylase and lipase diminished to $99 \mathrm{U} / \mathrm{L}$ and $87 \mathrm{U} / \mathrm{L}$ (respectively) six day after discontinuation of steroid therapy. She was discharged from the gastroenterology unit on the ninth day of hospitalization. Whereas AP related to drug is rare, abdominal pain, nausea and vomiting during steroid therapy make the physician consider AP for the differential diagnosis.
\end{abstract}

Keywords: Steroide, pancreatitis, emergency Received: 13.04.2011 Accepted: 13.06.2011

\section{ÖZET}

Akut pankreatit (AP) tipik olarak karın ağrısı ile başlayan ve genellikle pankreasın inflamatuvar hastalığı sonucu kan ve idrarda pankreas enzimlerinin yüksekliği ile birlikte seyreden akut bir klinik tablodur. Yirmi beş yaşında bayan hasta yaklaşık 4 gündür devam eden, sırta vuran tarzda ve sürekli vasıfta karın ağıısı, bulantı, kusma yakınmalarıyla acil servise başvurdu. Hastanın özgeçmişinde bilinen sistemik bir hastalığı olmadığı, 15 gün önce ürtiker nedeniyle yapılan toplam 120 mg Metilprednizolon (IV) sonrasında karın ağrısının başladığı öğrenildi. Yapılan fizik muayenesinde konjuktivaları soluk, skleralar subikterik, epigastrik bölgede hassasiyet ve minimal rebound tespit edildi. Laboratuvarda amilaz $957 \mathrm{U} / \mathrm{L}$ (Normal değer: 36-128) ve lipaz 1193 U/L (Normal değer: 22-51) düzeyleri yüksek tespit edildi. Bilgisayarlı üst-alt batın tomografisinde pankreas baş kısmı normalden geniş ve heterojen olarak tespit edildi. Komşuluğundaki duodenum II. kısmında hafif diffüz duvar kalınlaşması mevcuttu. Çekilen Manyetik Rezonans Kolanjiyo-Pankreatografi'si (MRCP) normal olarak değerlendirildi. Bu bulgular doğrultusunda hastaya AP tanısı konuldu. Etiyolojide ilaç kullanımı dışında AP'ye neden olabilecek başka bir patoloji saptanmadığı için steroid kesildi. Oral beslenmesi kesilerek, parenteral sıvı-elektrolit desteği sağlandı. Steroidin kesilmesinin 6. gününde pankreas enzim düzeyleri amilaz 99 U/L, lipaz 87 U/L olarak geriledi. Hasta yatışının 9. gününde Gastroenteroloji servisinden şifa ile taburcu oldu. İlaca bağlı AP nadir görülmekle birlikte, steroid kullanımı sonrasında gelişen karın ağrısı, bulantı ve kusma şikayetleri de AP tanısını akla getirmelidir.

Anahtar Kelimeler: Steroid, pankreatit, acil

Geliş Tarihi: 13.04.2011 Kabul Tarihi: 13.06.2011

\section{Giriş}

Akut pankreatit (AP) tipik olarak karın ağrısı ile başlayan ve genellikle pankreasın inflamatuvar hastalığı sonucu kan ve idrarda pankreas enzimlerinin yüksekliği ile birlikte seyreden akut bir klinik tablodur. Pankreasın inflamatuvar bir hastalığı olan AP etiyolojisinde yer alan pek çok faktörden birisi de ilaçlar ve toksinlerdir. AP'ye neden olan başlıca ilaçlar; Azotiopürin, Sulfonamid, Sulindak, Tetrasiklin, Valproik asit, Didanozin, Metildopa, Östrojen, Furosemid, 6 merkaptopürin, Pentamidin, 5-aminosalisilik asid, Kortikosteroid ve Oktreotid'dir. AP ile kesin olarak ilişkili olduğu bilinen ilaçların alımı kesilince klinik belirtiler düzelmekte, ilaç tekrar alındığında ise AP tablosu tekrar ortaya çıkmaktadır. Metil alkol, organik fosforlu insektisitler ve bazı tür akrep sokmaları da 
direkt toksik etki ile AP'ye neden olabilmektedir. Bu sunumda steroid kullanımına bağlı gelişen AP olgusu tartışılacaktır.

\section{Olgu Sunumu}

Yirmi beş yaşında bayan hasta yaklaşık 4 gündür devam eden, sırta vuran tarzda ve sürekli vasıfta karın ağrısı, bulantı, kusma yakınmalarıyla acil servise başvurdu. Hastanın özgeçmişinde bilinen sistemik bir hastalığı olmadığı, 15 gün önce ürtiker nedeniyle toplam 120 mg Metilprednizolon (IV) yapıldığı, sonrasında karın ağrısının başladığı öğrenildi. Hastanın geliş vital bulguları; kan basıncı: 130/80 mm/ hg, ateş: $36.7^{\circ} \mathrm{C}$, nabı: 104/dk idi. Yapılan fizik muayenesinde konjuktivaları soluk, skleralar subikterik, epigastrik bölgede hassasiyet ve minimal rebound tespit edildi. Laboratuvarda AST: $27 \mathrm{U} / \mathrm{L}$, ALT: $51 \mathrm{U} / \mathrm{L}, \mathrm{GGT}: 18 \mathrm{U} / \mathrm{L}$, Direkt Bilirübin: $0.1 \mathrm{mg} / \mathrm{dL}$, Indirekt Bilirübin: 0.4 mg/dL, trigliserit: 77 mg/dL, VLDL: 15.4 mg/dL, HDL: 42.0 mg/dL, LDL: 167.6 mg/dL, kolesterol: 225 mg/dL düzeyleri normal iken amilaz 957 U/L (Normal değer:36-128) ve lipaz 1193 U/L (Normal değer: 22-51) düzeyleri yüksek tespit edildi. Abdominal ultrasonda AP lehine bir bulgu saptanmadı. Bu nedenle çekilen bilgisayarlı üst-alt batın tomografisinde pankreas baş kısmı normalden geniş ve heterojen olarak tespit edildi (Resim 1). Komşuluğundaki duodenum II. kısmında hafif diffüz duvar kalınlaşması mevcuttu (Resim 2). Çekilen Manyetik Rezonans Kolanjiyo-Pankreatografi'si (MRCP) normal olarak değerlendirildi. Bu bulgular doğrultusunda hastaya AP tanısı konuldu. Etiyolojide ilaç kullanımı dışında AP'ye neden olabilecek başka bir patoloji saptanmadığı için steroid kesildi. Oral beslenmesi kesilerek, parenteral sıvı-elektrolit (2500 cc \%0.9 $\mathrm{NaCl}, 2500$ cc \%5 dekstroz) desteği sağlandı. Steroidin kesilmesinin 6.gününde pankreas enzim düzeyleri amilaz $99 \mathrm{U} / \mathrm{L}$, lipaz $87 \mathrm{U} / \mathrm{L}$ olarak geriledi. Hasta yatışının 9. gününde Gastroenteroloji servisinden şifa ile taburcu oldu.

\section{Tartışma}

Akut pankreatite yol açtığı bildirilen ilaç sayısı 85'den fazladır. Bunların 20'si kesin olarak etkili bulunmuştur (1). En yüksek insidanslar didanosine'de \%23, merkaptotopurinde ve azotiopurinde \%3 olarak tespit edilmiştir (2). Illaçların bazıları bir tür hipersensivite reaksiyonuna yol açarak bir ay kadar sonrasında AP'ye neden olmaktadır. Bir

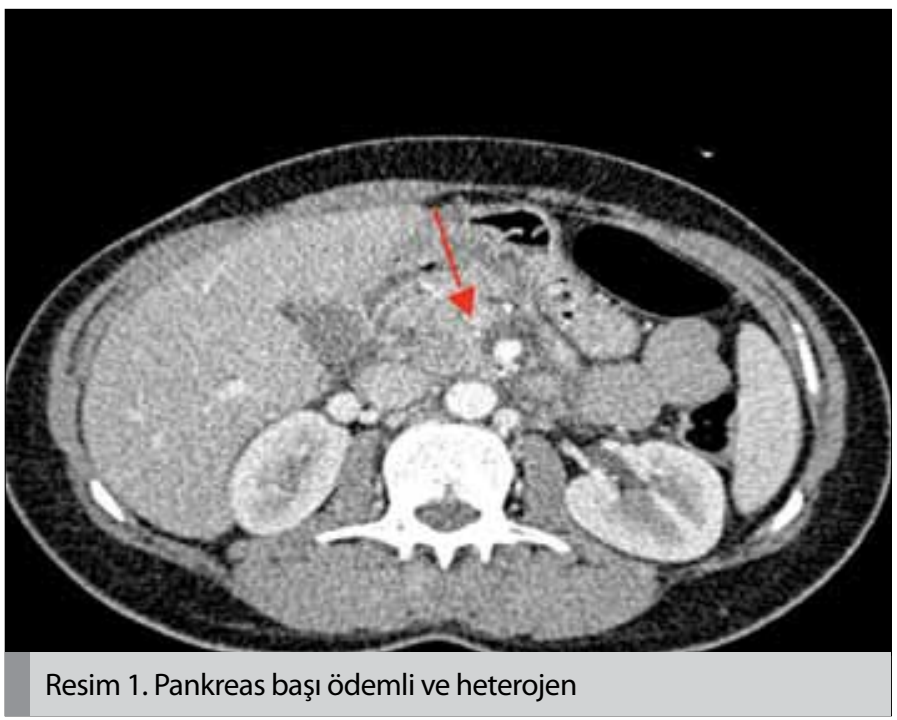

kısmı ise toksik metabolitlerin birikmesi sonucunda ve asetaminofen ise bir tek aşırı dozda bile AP'ye neden olmaktadır. Etil alkol ise en önde gelen AP nedenidir. Ayrıca metil alkolde benzer etkileri göstermektedir. Yılan zehiri ve fosforlu insektisitlerinde AP etiyolojisinde yer aldığı bildirilmektedir $(3,4)$.

Akut pankreatit, birçok nedene bağlı olarak meydana gelmekte ve steroid gibi ilaçlar da AP nedeni olabilmektedir (5). Steroid ile ilişkili pankreatit için ileri sürülen mekanizma serbest radikallerin, sitokinlerin intrasellüler adhezyon molekülü-1 (ICAM-1) ve onun kontur reseptörü olan lenfosit fonksiyonel antijeni (LFA), makrofaj adezyon molekülü-1 (Mac-1) gibi moleküllerin pankreatik hücre endotelyal bariyeri üzerindeki direkt toksik etkisidir (6). Ayrıca steroid kullanımı hiperlipidemi seviyesini artırarak AP neden olabilmektedir (7). AP tanısı laboratuvar bulgusu ve klinik semptomlara dayanır. Tek bir tanısal testin bulunmamasına rağmen artmış serum amilaz konsantrasyonlarına abdominal ağrının eşlik ettiği durumlar tanı açısından anahtar rol oynar (7). Steroid alan hastalarda serum lipaz düzeyleri de artmaktadır. Steroid tedavisi sırasında AP gelişimi ile yaş, cinsiyet, altta yatan hastalık, tedavi süresi arasında ilişki saptanamamıştır. Bu nedenle AP tanısı konulan olguların etyolojisinde ilaç kullanımı, süre ve dozdan bağımsız olarak mutlaka göz önünde bulundurulmalıdır.

Pankreatitle ilişkili olduğu bilinen ilacın kesilmesinin ardından klinik tablo gerilese de, ilacın tekrar alınmasıyla pankreatitin yinelemesi nedeniyle, kullanılan ilacın etiyolojik faktör olarak belirlenmesi tedavi yanında prognoz açısından da büyük önem taşımaktadır.

Illaca bağlı AP tanısı nadir görülmekle beraber insidansı ancak vaka raporlarından tahmin edilmektedir. Vinklerova ve ark. (8) AP etiyolojisine yönelik yaptıkları resrospektif bir çalışmada ilaca bağlı AP vakalarını \%5.3 (8 kişi) oranında ve üçüncü en sık neden olarak rapor etmişlerdir. Bunların içinde bir vaka da folliküler lenfoma tanısıyla beş gün Deksametazon kullanımına bağlı gelişen AP vakası bildirilmiştir. Illaca bağlı pankreatit olgularının genç, bayan ve Crohn hastalığında daha fazla görüldüğü vurgulanmıştır. Bizim vakamızda 25 yaşında, bayan hastaydı ancak bilinen sistemik bir rahatsızığı yoktu.

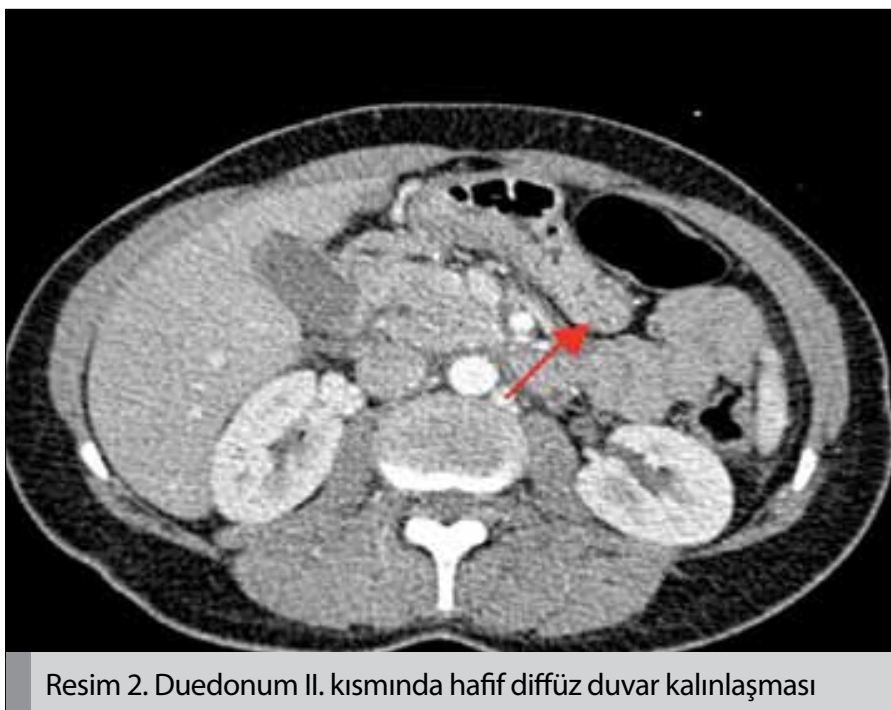


Khanna ve ark.'ları (9) olgu sunumunda 18 yaşında, Ülseratif Kolit nedeniyle takip edilen erkek hastayı rapor etmişlerdir. 100 mg/6saatte-bir kez (iV) Hidrokortizon başlanan ve tedavinin 2. günü gelişen epigastrik ağı ve pankreatik enzim yükselmesi nedeniyle yapılan ultrosonografi'de AP tanısı alan hasta Hidrokortizon kesilip, tedavisi düzenlendikten yedi gün sonra taburcu edilmiştir. Bizim hastamızda medikal tedavi ile takip sonrası dokuzuncu gününde taburcu edilmiştir.

Yoshizawa ve ark.'ları da (10) prospektif çalışmalarında bullous pemphigoid nedeniyle yedi hastada verilen $30 \mathrm{mg}$ oral prednizolon tedavisi sonrası pankreas enzimlerinin yükseldiğini tespit etmişlerdir. Yine başka bir olgu sunumundan da bahsetmişlerdir. 80 yaşında bayan hasta pemfigus nedeniyle $1 \mathrm{~g}$ Metilprednizolon ile pulse steroid tedaviye $30 \mathrm{mg}$ oral prednizolon eklenerek takip edilmiş ve tedavinin 4.günü amilaz düzeyinin yükseldiği görülmüştür. Yoshizawa ve ark.'ları (10) AP gelişimi için 25 mg'dan daha düşük dozların bile yeterli olabileceğini belirtmişlerdir. Bizim vakamızda ise toplam doz 120 mg idi ve ilacın kesilmesini takiben altıncı gün pankreas enzimleri normal seviyeye gerilemiştir.

Literatürde steroid tedavisine bağlı gelişen AP vakasının az sayıda olduğu dikkati çekmiştir. Bu konuda yapılacak olan daha geniş ve kapsamlı çalışmalara ihtiyaç olduğunu düşünmekteyiz.

\section{Sonuç}

Akut pankreatit yüksek morbidite ve mortalitesi olan bir hastalıktır. Illaca bağlı AP nadir görülmekle birlikte, steroid kullanımı sonrasında gelişen karın ağrısı, bulantı ve kusma şikayetleri de AP tanısını akla getirmelidir.

\section{Çıkar çatışması}

Yazarlar herhangi bir çıkar çatışması bildirmemişlerdir.

\section{Kaynaklar}

1. Mallory A, Kern F Jr. Drug induced pancreatitis a critical review: Gastroenterology 1980; 78: 813-20.

2. Haber CJ, Meltzer SJ, Present DH, Korelitzs BI. Nature and course of pancreatitis caused by 6 mercaptopurine in the treatment of inflammatory bowell disease. Gastroenterology 1986; 91: 982-6.

3. Bartholomew C, Acute Scorpion pancreatitis in Trinidad. BMJ 1970; 1: 666-8. [CrossRef]

4. Lee HS. Acute pancreatitis and organophosphate poisoning:a case report and review. Singapore Med J 1989; 30: 599-601.

5. Pellock JM, Wilder BJ, Deaton R, Sommerville KW. Acute pancreatitis COincident with valproat use: a critical review. Epilepsia 2002; 43: 1421-4. [CrossRef]

6. Kingsnorth A. Role of cytokines and their inhibitors in acute pankreatittis. Gut 1997; 34: 1-4

7. Bhavsar B, Bhatt A. Steroid Induced Hyperlipidemic Pancreatitis and New Onset Diabetes Mellitus. JOP J Pancreas (online) 2008; 9: 664-6.

8. Vinklerova I, Prochazka M, Prochazka V, Urbanek K. Incidence, severity, and etiology of drug-induced acute pancreatitis. Dig Dis Sci 2010; 55: 2977-81. [CrossRef]

9. Khanna S, Kumar A. Acute pancreatitis due to hydrocortisone in a patient with ulcerative colitis. J Gastroenterol Hepatol 2003; 18: 1110-1. [CrossRef]

10. Yoshizawa Y, Ogasa S, Izaki S, Kitamura K. Corticosteroid-induced pancreatitis in patients with autoimmune bullous disease: case report and prospective study. Dermatology 1999; 198: 304-6. [CrossRef] 